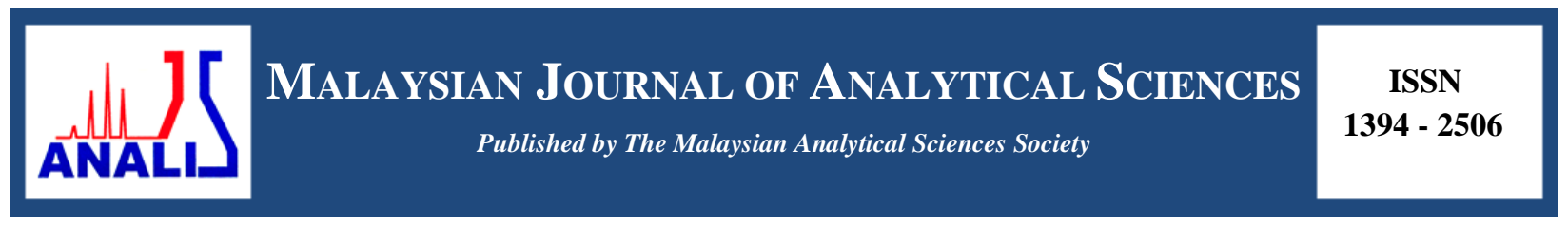

\title{
DETERMINATION OF NATURAL RADIOACTIVITY AND HEAVY METALS AT THE FORMER MINING SITE OF KOLEJ UNIVERSITI ISLAM ANTARABANGSA SELANGOR (KUIS) LAKE
}

\author{
(Penentuan Keradioaktifan Tabii dan Logam Berat di Kawasan Bekas Lombong Tasik Kolej \\ Universiti Islam Antarabangsa Selangor (KUIS))
}

\author{
Nur Ain Mohd Radzali, Norsyahidah Mohd Hidzir*, Irman Abdul Rahman \\ Nuclear Technology Research Centre, School of Applied Physics, \\ Faculty of Science and Technology, \\ Universiti Kebangsaan Malaysia, 43600 UKM Bangi, Selangor, Malaysia \\ *Corresponding author: syahidah@ukm.edu.my
}

Received: 29 August 2017; Accepted: 15 August 2018

\begin{abstract}
An ex-mining site has created an undesirable effect on the environment, such as the destruction of plants and contamination. Thus, this study was conducted to determine the natural radioactivity and heavy metal presence in the ex-mining site at Kolej University Islam Antarabangsa Selangor (KUIS) lake. Both parameters were measured using gamma spectrometry and inductively coupled plasma-mass spectrometry (ICP-MS). The results showed that the concentrations of ${ }^{238} \mathrm{U}(0.44 \pm 0.31 \mathrm{~Bq} / \mathrm{L})$, ${ }^{232} \mathrm{Th}(0.04 \pm 0.02 \mathrm{~Bq} / \mathrm{L}),{ }^{226} \mathrm{Ra}(0.19 \pm 0.11 \mathrm{~Bq} / \mathrm{L})$, and ${ }^{40} \mathrm{~K}(0.62 \pm 0.37 \mathrm{~Bq} / \mathrm{L})$ in water samples were below the recommended values by the World Health Organization (WHO) for drinking water source, which implied the safe consumption of the water. However, the presence of ${ }^{238} \mathrm{U},{ }^{232} \mathrm{Th},{ }^{226} \mathrm{Ra}$, and ${ }^{40} \mathrm{~K}$ in sediment samples exceeded the limit proposed by UNSCEAR, with the radioactivity of $49.1 \pm 18.8 \mathrm{~Bq} / \mathrm{kg}, 102.3 \pm 3.3 \mathrm{~Bq} / \mathrm{kg}, 133.2 \pm 18.8 \mathrm{~Bq} / \mathrm{kg}$, and $297.1 \pm 25.7 \mathrm{~Bq} / \mathrm{kg}$, respectively. For heavy metal determination, zinc was found in the sediment with the highest concentration $(17.34 \pm 15.79 \mathrm{mg} / \mathrm{kg})$ compared to other heavy metals, while the concentration of arsenic was highest in water with $0.58 \pm 0.26 \mu \mathrm{g} / \mathrm{L}$. All hazard indices were found to be below the safety limit except for the gamma index of $1.6 \pm 0.7 \mathrm{~Bq} / \mathrm{kg}$ and $104.1 \pm 48.4 \mathrm{nGy} / \mathrm{h}$ for the gamma dose rate.
\end{abstract}

Keywords: radioactivity, heavy metals, water, sediment, gamma spectrometry

\section{Abstrak}

Tapak bekas lombong telah meninggalkan impak yang tidak diingini kepada alam sekitar seperti pemusnahan tanaman dan pencemaran. Oleh itu, kajian ini dijalankan untuk menentukan kehadiran radionuklid tabii dan logam berat di tapak bekas perlombongan di tasik Kolej Universiti Islam Antarabangsa Selangor (KUIS). Kedua-dua parameter ini diukur menggunakan spektrometri gama dan spektometer jisim-gandingan plasma teraruh (ICP-MS). Hasil kajian menunjukkan kepekatan ${ }^{238} \mathrm{U}(0.44$ $\pm 0.31 \mathrm{~Bq} / \mathrm{L}),{ }^{232} \mathrm{Th}(0.04 \pm 0.02 \mathrm{~Bq} / \mathrm{L}),{ }^{226} \mathrm{Ra}(0.19 \pm 0.11 \mathrm{~Bq} / \mathrm{L})$ dan ${ }^{40} \mathrm{~K}(0.62 \pm 0.37 \mathrm{~Bq} / \mathrm{L})$ berada di bawah nilai yang disyorkan oleh WHO untuk sumber air minuman, menunjukkan air berada ditahap selamat untuk diminum. Walau bagaimanapun, kehadiran ${ }^{238} \mathrm{U},{ }^{232} \mathrm{Th},{ }^{226} \mathrm{Ra}$ and ${ }^{40} \mathrm{~K}$ dalam sampel sedimen melebihi had yang dicadangkan oleh UNSCEAR, dengan kepekatan $49.1 \pm 18.8 \mathrm{~Bq} / \mathrm{kg}, 102.3 \pm 3.3 \mathrm{~Bq} / \mathrm{kg}, 133.2 \pm 18.8 \mathrm{~Bq} / \mathrm{kg}$ dan $297.1 \pm 25.7 \mathrm{~Bq} / \mathrm{kg}$. Bagi penentuan logam berat, didapati zink menunjukkan kepekatan tertinggi dalam sedimen $(17.34 \pm 15.79 \mathrm{mg} / \mathrm{kg})$ berbanding dengan logam berat lain, manakala kepekatan arsenik adalah tertinggi dalam air dengan $0.58 \pm 0.26 \mu \mathrm{g} / \mathrm{L}$. Semua indeks bahaya didapati berada di bawah had keselamatan kecuali indeks gamma iaitu 1.6 $\pm 0.7 \mathrm{~Bq} / \mathrm{kg}$ dan $104.1 \pm 48.4 \mathrm{nGy} / \mathrm{h}$ untuk kadar dos gama.

Kata kunci: radioaktiviti, logam berat, air, sedimen, spektrometri gama 


\section{Nur Ain et al: DETERMINATION OF NATURAL RADIOACTIVITY AND HEAVY METALS AT THE FORMER MINING SITE OF KOLEJ UNIVERSITI ISLAM ANTARABANGSA SELANGOR (KUIS) LAKE}

\section{Introduction}

Exposure to either natural radiation or manufactured radiation sources can be dramatically enhanced through human practices. For example, fertilizer production and mining activities can result in the increase of natural radiation exposure. Uranium-238 $\left({ }^{238} \mathrm{U}\right)$, thorium-232 $\left({ }^{232} \mathrm{Th}\right)$, and potassium- $40\left({ }^{40} \mathrm{~K}\right)$ are the examples of primordial elements that naturally exist in the earth's crust, while radium-226 $\left({ }^{226} \mathrm{Ra}\right)$ is the progeny of ${ }^{238} \mathrm{U}$ and ${ }^{232} \mathrm{Th}$. Radionuclides can be transferred from the soil to the human body in various pathways and have a greater potential to damage the cells once they enter the body. Based on the amount of radiation exposure, many unwanted biological effects may occur, such as cell alteration [1]. One of the radionuclides that is well known to be chemically toxic is ${ }^{226} \mathrm{Ra}$. In addition, ${ }^{226} \mathrm{Ra}$ tends to be collected in the bones if ingested into the body, which later may result in either leukaemia or bone cancer [2].

Recently, many abandoned mining lakes in Malaysia have been converted into more economical areas, such as recreational and residential areas. Human-made activities around the ex-mining lake can result in the enrichments of radionuclides and heavy metals surrounding the lake. Kolej University Islam Antarabangsa Selangor (KUIS) lake is an ex-mining lake with an estimated area of $0.09 \mathrm{~km}^{2}$, located at Bangi Lama, Selangor. Many recreational activities have been conducted around the lake, such as canoeing and fishing competitions. The determination of concentration of naturally occurring radioactive materials (NORM) present in water and sediments around the KUIS lake is an effort of better understanding the spatial distribution of the radionuclides and their associated health hazards [3]. In addition to being the main source of radiation exposure to humans, the soil acts as a medium of migration for transfer of radionuclides to the biological systems; hence, it is the basic indicator of radiological contamination in the environment $[4,5]$. Therefore, research on the intake of NORM and heavy metals in KUIS lake is performed to evaluate the safety aspect of the people surrounding the lake. The concentration of radionuclides ${ }^{238} \mathrm{U},{ }^{232} \mathrm{Th},{ }^{226} \mathrm{Ra}$, and ${ }^{40} \mathrm{~K}$ and heavy metals in water and sediment is a good indicator of the presence of hazards in that area. The main objective is to evaluate the safety level of the former mining area because research has shown that exposure to radiation could lead to lung, pancreas, skin, and kidney cancer [6]. Knowledge of natural radioactivity present in sediment and water is important to assess any possible radiological hazard indices associated with exposure to humans.

\section{Materials}

\section{Materials and Methods}

Water and sediment samples were taken at four different locations around KUIS lake; represented as K1, K2, K3, and K4 (refer to Figure 1). The average reading of sample at K1 to K4 were taken to represent the activity presence at KUIS lake with the label of $\mathrm{K}^{\mathrm{w}}$ for average concentration of radionuclides and heavy metals in water, whereas $\mathrm{K}^{\mathrm{s}}$ represents the average concentration of radionuclides and heavy metals in sediment. Controlled sample was taken along Semenyih river and labelled as $S^{\mathrm{w}}$ for concentration of radionuclides and heavy metals in water, whereas $\mathrm{S}^{\mathrm{s}}$ represents concentration of radionuclides and heavy metals in sediment. Hydrochloride acid (purity 36.5-38\%) and nitric acid (purity 69\%-70\%) were obtained from JT Baker.

\section{Pre-treatment of samples}

About $6 \mathrm{~L}$ of water sample and $3 \mathrm{~kg}$ of sediment sample were collected with three replicates in single sampling from each station (K1 to $\mathrm{K} 4, \mathrm{~S}^{\mathrm{w}}$, and $\mathrm{S}^{\mathrm{s}}$ ). The water sample was collected based on the standard procedure for water analysis study [7]. For water sample, four parameters: $\mathrm{pH}$, conductivity, dissolved oxygen and temperature, were determined using a pH meter (WITEG W 100), a conductivity meter (YSI SCT Model 33), and an oxygen meter (HANNA instruments HI 91942), respectively [8]. About a 2-L sample of water was concentrated to $200 \mathrm{~mL}$ by heating the water at $60^{\circ} \mathrm{C}$. For NORM analysis, the water sample was filled inside the polyethylene container to a height of $4 \mathrm{~cm}$ and kept for 30 days to reach the secular equilibrium before being analysed by a highly pure germanium (HPGe) detector (Canberra Model GC1018). For heavy metal analysis, approximately a 100-mL sample of water was filtered using filter paper and kept in a bottle before being analysed by inductively coupled plasmamass spectrometry (ICP-MS) model (ELAN® DRC-E, Perkin Elmer Elan 9000) [8]. For NORM analysis of the sediment sample, the sediment was first weighed and dried in the oven before sieved through 500 micrometer sieve to obtain a uniform distribution of sediment [9]. Then, the sample was kept for 30 days inside a polyethylene container ( $4 \mathrm{~cm}$ height) to reach a secular equilibrium before being analysed by the HPGe detector. For heavy metal 
analysis, the digestion method was used with approximately $0.1 \mathrm{~g}$ of sediment sample placed in the solution containing a mixture of $6 \mathrm{~mL}$ of hydrochloric acid and $4 \mathrm{~mL}$ of nitric acid. Then, the solution mixture was digested using the microwave digestive system for two hours until a clear solution formed [8] before further analysis by ICPMS.

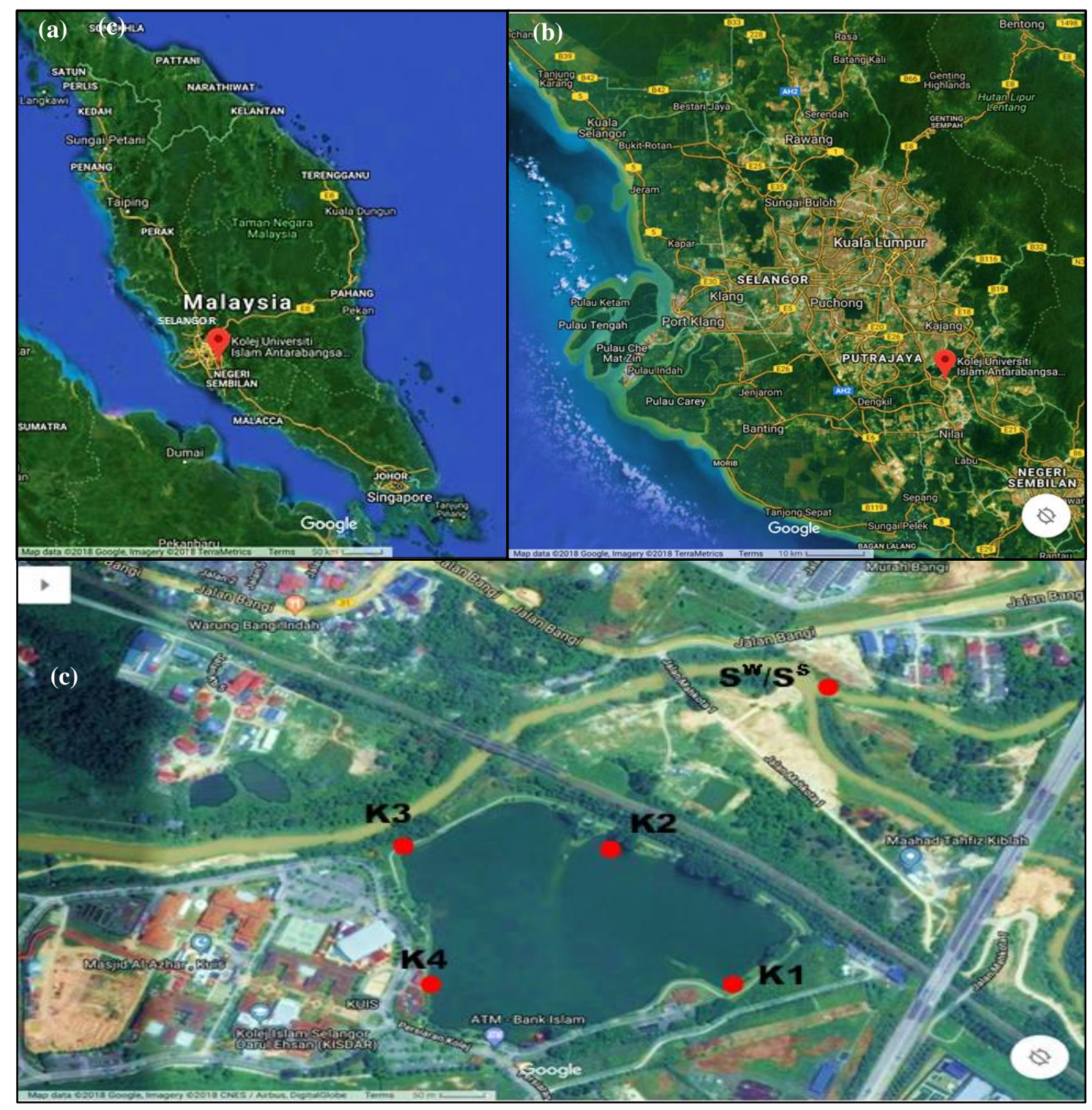

Figure 1. Geographical map of (a) peninsular Malaysia, (b) Selangor state and (c) location of the sampling site.

\section{Characterisation}

The concentration of radionuclides in water and sediment samples was determined using the HPGe detector (Canberra Model GC1018) at Nuclear Science Laboratory at UKM. The calibration of the machine was made using a standard source. Both samples and background were counted for 12 hours. The concentration of radionuclide in the water sample was determined by plotting the efficiency curve of the multi-nuclide standard solution. The specific activity $\left(\mathrm{A}_{\mathrm{s}}\right)$ of radionuclides in the water sample was determined using the formula in equation 1 [10]: 
Nur Ain et al: DETERMINATION OF NATURAL RADIOACTIVITY AND HEAVY METALS AT THE FORMER MINING SITE OF KOLEJ UNIVERSITI ISLAM ANTARABANGSA SELANGOR (KUIS) LAKE

$$
A_{s}\left(\frac{B q}{L}\right)=\frac{N}{\varepsilon \times P \gamma \times V},
$$

where $N$ is the corrected net peak area background (cps), $\varepsilon$ is the efficiency of the detector for a $\gamma$-ray interest (cps/Bq), $P \gamma$ is the branching ratio of elements (\%), and $V$ is the volume of the water sample (L). The concentration of radionuclides in the sample was determined from the net counts of the sample obtained using the multichannel analyser (Software Genie 2000) by referring to the peak energy of $1764 \mathrm{keV}$ for ${ }^{238} \mathrm{U}, 1460 \mathrm{keV}$ for ${ }^{40} \mathrm{~K}, 2614 \mathrm{keV}$ for ${ }^{232} \mathrm{Th}$, and $609 \mathrm{keV}$ for ${ }^{226} \mathrm{Ra}$.

The concentration of radionuclides in the sediment sample $\left(W_{s}\right)$ was determined using a comparison technique in which the activity of the sample was compared with the standard of IAEA-375. The concentration was calculated using the formula in equation 2 [11]:

$$
W_{s}\left(\frac{B q}{k g}\right)=\frac{M_{P}}{M_{s}} \times \frac{A_{s}}{A_{p}} \times W_{p},
$$

where $M_{p}$ and $M_{s}$ are the mass of the standard and sample $(\mathrm{kg})$, respectively, and $A_{p}$ and $A_{s}$ are the activity of the standard and sample (cps), respectively, while $W_{p}$ is the concentration of radionuclides in the standard (Bq/kg).

The concentration of heavy metals in the water and sediment samples was determined using ICP-MS model (ELAN® DRC-E, Perkin Elmer Elan 9000) at Environmental Science Laboratory UKM. The total count technique was used and heavy elements, such as arsenic (As), barium (Ba), cadmium (Cd), copper $(\mathrm{Cu})$, mercury $(\mathrm{Hg})$, manganese (Mn), antimony (Sb), strontium ( $\mathrm{Sn})$, and zinc $(\mathrm{Zn})$, were chosen in these studies based on their toxicity, which can result in hazards to the environment. The concentration of heavy metals $(C)$ in the sediment sample was calculated using the formula in equation 3 [12]:

$$
C\left(\frac{B q}{k g}\right)=\frac{N \times V}{M},
$$

where $N$ is the concentration of radionuclides $(\mu \mathrm{g} / \mathrm{L}), V$ is the volume of solution (L), and $M$ is the mass of dried sample used during digestion process $(\mathrm{g})$.

\section{Statistical analysis}

All statistical tests were performed using the Statistical Package for the Social Sciences (SPSS) software package (IBM SPSS Statistic 22). The $T$-test was performed and significances were defined as $p<0.05$, if not stated otherwise [13].

\section{Radiological hazard}

Radium equivalent activity index $\left(R a_{e q}\right)$ was introduced to compare the specific activity of a sample, which have different concentrations of ${ }^{232} \mathrm{Th},{ }^{226} \mathrm{Ra}$, and ${ }^{40} \mathrm{~K}$ [14]. Moreover, $R a_{e q}$ is defined as the total activity of the three radionuclides based on the estimation that $370 \mathrm{~Bq} / \mathrm{kg}$ of ${ }^{226} \mathrm{Ra}, 259 / \mathrm{kg}$ of ${ }^{232} \mathrm{Th}$, and $4810 \mathrm{~Bq} / \mathrm{kg}$ of ${ }^{40} \mathrm{~K}$ produced the same dose rates. The $R a_{e q}$ is related to the external and internal $\gamma$-dose due to radon and its daughter. The maximum value of $R a_{e q}$ for a safe limit is $370 \mathrm{~Bq} / \mathrm{kg}$ [15]. In addition, $R a_{e q}$ was determined using the formula in equation (4).

The Gamma Index $\left(I_{\gamma}\right)$ was used to estimate the gamma radiation hazard levels associated with natural radionuclides. These indexes can be determined using the formula in equation (5), derived by the Nuclear Energy Agency-Organisation for Economic Co-operation and Development (NEA-OECD) 1979 [15]. The safe value for $I_{\gamma}$ is $\leq 1[16]$.

The External Hazard Index $\left(H_{e x}\right)$ was determined to estimate the external hazard received by the people. The $H_{e x}$ was calculated using the formula in equation (6). The safe value of this index was $\leq 1$ [17].

The total exposure was also donated by the internal exposure from radionuclide, such as radon, which can affect the respiratory organs. Therefore, the Internal Hazard Index $\left(H_{\text {in }}\right)$ was determined in this study. The value for $H_{\text {in }}$ was calculated using the formula in equation (7). The value for $H_{\text {in }}$ must be $\leq 1$ for the radiation hazard to be negligible [17]. 
Absorb dose rate $(D)$ was determined in this study. In addition, $D$ is defined as the average activity concentration of ${ }^{40} \mathrm{~K},{ }^{226} \mathrm{Ra}$, and ${ }^{232} \mathrm{Th}$ in the air at the height of $1.0 \mathrm{~m}$ above the surface [18]. According to UNSCEAR (2000) [19], $D$ can be calculated using formula in equation (8).

$$
\begin{aligned}
& R a_{e q}\left(\frac{B q}{k g}\right)=A_{R a}+1.43 A_{T h}+0.077 A_{K}, \\
& I_{\gamma}=\frac{A R a}{150}+\frac{A_{T h}}{100}+\frac{A_{K}}{1500} \leq 1, \\
& H_{e x}=\frac{A R a}{370}+\frac{A_{T h}}{259}+\frac{A_{K}}{4810} \leq 1, \\
& H_{\text {in }}=\frac{A R a}{185}+\frac{A_{T h}}{259}+\frac{A_{K}}{4810} \leq 1, \\
& D\left(\frac{n G y}{h}\right)=0.462 A_{R a}+0.621 A_{T h}+0.0417 A_{K},
\end{aligned}
$$

where $A_{R a}, A_{T h}$, and $A_{k}$ in the formulas in equations (4) to (8) are specific activity concentrations in $\mathrm{Bq} \cdot \mathrm{kg}^{-1}$ of ${ }^{226} \mathrm{Ra}$, ${ }^{232} \mathrm{Th}$, and ${ }^{40} \mathrm{~K}$, respectively.

The estimated annual effective dose rate $\left(D_{\text {eff }}\right)$ was calculated in this study using the formula in equation (9) [19].

$$
D_{\text {eff }}\left(\frac{m S v}{t}\right)=D\left(\frac{n G y}{h}\right) \times 8760\left(\frac{h}{t}\right) \times 0.2 \times 0.7\left(\frac{S v}{G y}\right) \times 10^{-6},
$$

where $0.7 \mathrm{~Sv} / \mathrm{Gy}$ was taken as the conversion coefficient from the absorbed dose in the air, and the outdoor occupancy factor (0.2) was taken from UNSCEAR 2000 [19].

\section{Physical parameter of water}

\section{Results and Discussion}

The physical parameters of water, including $\mathrm{pH}$, conductivity, dissolved oxygen (DO), and temperature, at each station were determined in this study. The results are presented in Table 1 . The $\mathrm{pH}$ level of water can influence the solubility of the radionuclides and heavy metals in water [20]. From this study, an average pH of 6 was recorded for the water sample in the KUIS lake $\left(\mathrm{K}^{\mathrm{w}}\right)$ and a $\mathrm{pH}$ of 6.2 was found in the control sample $\left(\mathrm{S}^{\mathrm{w}}\right)$, which indicated that both water samples were slightly acidic and that no significant difference was found between those two locations $(p=0.44)$. A previous study by Ashraf et al. [21] found a similar trend for the acidic water parameter with a $\mathrm{pH}$ level of $5.71 \pm 0.52$ at an ex-mining area in Bestari Jaya, Kuala Selangor. A similar observation was also reported by Al-Badaii et al. [22] in the Semenyih River (similar river at $S^{\mathrm{w}}$ ) with a $\mathrm{pH}$ between 5.23 and 6.55, which was in the range of the current study. According to National Lake Water Quality Criteria and Standards (NLWQS), the $\mathrm{pH}$ value range between 6 and 9 is classified as category C [23]. Thus, KUIS lake in this study fell into this category (category $\mathrm{C}$ ) from NLWQS, which indicated that the $\mathrm{pH}$ of the lake is good for the preservation of aquatic living and biodiversity [23]. An average temperature in the $\mathrm{K}^{\mathrm{w}}$ was recorded at $30.7^{\circ} \mathrm{C}$ similar to $\mathrm{S}^{\mathrm{w}}\left(29.5^{\circ} \mathrm{C} \pm 0.2^{\circ} \mathrm{C}\right)$ and statistical differences were not found between those two locations $(p=0.5)$.

Table 1. Physical parameters of water

\begin{tabular}{llcccc}
\hline Sample & Location & $\mathbf{p H}$ & $\begin{array}{c}\text { Conductivity } \\
(\boldsymbol{\mu S} / \mathbf{c m})\end{array}$ & $\begin{array}{c}\text { Temperature } \\
\left({ }^{\circ} \mathbf{C}\right)\end{array}$ & $\begin{array}{c}\text { Dissolved Oxygen } \\
(\mathbf{m g} / \mathbf{L})\end{array}$ \\
\hline $\mathbf{K}^{\mathbf{w}}$ & KUIS lake & $6.0 \pm 0.1$ & $13.8 \pm 5.8$ & $30.7 \pm 1.2$ & $5.6 \pm 0.5$ \\
$\mathbf{S}^{\mathbf{w}}$ & $\begin{array}{l}\text { Semenyih River } \\
\text { (control) }\end{array}$ & 6.2 & $52.8 \pm 0.2$ & $29.5 \pm 0.2$ & $6.1 \pm 0.1$ \\
\hline
\end{tabular}

$\mathrm{K}^{\mathrm{w}}$ Average value for $\mathrm{K} 1, \mathrm{~K} 2, \mathrm{~K} 3$, and $\mathrm{K} 4$ in water sample

Dissolved oxygen in water is essential for the metabolism of all aquatic organisms. An average of dissolved oxygen in the $\mathrm{K}^{\mathrm{w}}$ was lower $(5.6 \pm 0.5 \mathrm{mg} / \mathrm{L})$ compared to the $\mathrm{S}^{\mathrm{w}}(6.1 \pm 0.1 \mathrm{mg} / \mathrm{L})$. The dissolved oxygen in $\mathrm{K}^{\mathrm{w}}$ was lower compared to the control sample $\left(\mathrm{S}^{\mathrm{w}}\right)$ possibly because of a large amount of dissolved organic matter present near the 


\section{Nur Ain et al: DETERMINATION OF NATURAL RADIOACTIVITY AND HEAVY METALS AT THE FORMER MINING SITE OF KOLEJ UNIVERSITI ISLAM ANTARABANGSA SELANGOR (KUIS) LAKE}

surface of $\mathrm{K}^{\mathrm{w}}$, which causes undersaturated dissolved oxygen [24]. An aquatic organism process, such as photosynthesis of the algae in $S^{\mathrm{w}}$, might result in the increase of oxygen concentration at $\mathrm{S}^{\mathrm{w}}$ compared to $\mathrm{K}^{\mathrm{w}}$. Referring to NLWQS Malaysia, the dissolved oxygen in water in the current study was classified as category B or C (dissolved oxygen ranged from 5.5-8.7 mg/L for category B and 4.5-10.3 mg/L for category $\mathrm{C}$ ), in which the dissolved oxygen for class B indicates that the lake is also suitable for secondary body contact recreational purposes, such as boating, but is not suitable for swimming activities [23]. The capability of water to pass the electrical flow (conductivity of water) was measured through a conductivity meter. The conductivity of the water for $\mathrm{K}^{\mathrm{w}}$ was $13.8 \mu \mathrm{S} / \mathrm{cm}$, which is significantly lower that that of $\mathrm{S}^{\mathrm{w}}(2.8 \pm 0.2 \mu \mathrm{S} / \mathrm{cm})(p=0.01)$. Generally, most of the freshwater conductivity ranges from 10 to $1000 \mu \mathrm{S} / \mathrm{cm}$ but may also exceeded $1000 \mu \mathrm{S} / \mathrm{cm}$ for polluted water or places with land run-off [25]. The conductivity of water in both of the samples $\left(\mathrm{K}^{\mathrm{w}}\right.$ and $\left.\mathrm{S}^{\mathrm{w}}\right)$ indicates that the water was clean and free from any pollution.

\section{Radionuclides concentration}

The concentration of ${ }^{238} \mathrm{U},{ }^{232} \mathrm{Th},{ }^{226} \mathrm{Ra}$, and ${ }^{40} \mathrm{~K}$ in water samples were calculated using equation (1) and presented in Table 2. The current study showed that all radionuclides $\left({ }^{40} \mathrm{~K},{ }^{226} \mathrm{Ra},{ }^{232} \mathrm{Th}\right.$, and $\left.{ }^{238} \mathrm{U}\right)$ were detected in the water sample of KUIS lake $\left(\mathrm{K}^{\mathrm{w}}\right)$. The highest concentration of ${ }^{40} \mathrm{~K}(0.62 \pm 0.37 \mathrm{~Bq} / \mathrm{L})$ was observed in the water sample compared to other radionuclides, possibly due to the natural existence of ${ }^{40} \mathrm{~K}$ in the rocks and on the earth's crust $[26,27]$. However, all radionuclides were not detected in the control sample $\left(S^{\mathrm{w}}\right)$, except for ${ }^{232} \mathrm{Th}(0.13 \pm 0.01$ $\mathrm{Bq} / \mathrm{L}$ ). The presence of all radionuclides in $\mathrm{K}^{\mathrm{w}}$ compared to $\mathrm{S}^{\mathrm{W}}$ might possibly prove that the mining activity in the past in $\mathrm{K}^{\mathrm{W}}$ can result in the enhancement of natural radionuclides in the water sample. The concentration of ${ }^{238} \mathrm{U}$ in $\mathrm{K}^{\mathrm{w}}$ was higher compared to ${ }^{232} \mathrm{Th}$, possibly due to the higher solubility of ${ }^{238} \mathrm{U}$ in water compared to ${ }^{232} \mathrm{Th}$ in an acidic condition (current study with $\mathrm{pH}$ of 6) [28]. In addition, the lower concentration of ${ }^{232} \mathrm{Th}$ in the water samples of $\mathrm{K}^{\mathrm{w}}$ compared to ${ }^{238} \mathrm{U}$ could possibly be due to the transportation of ${ }^{232} \mathrm{Th}$ with particulate matter and subsequent deposit in the sediment. Therefore, the concentration of ${ }^{232} \mathrm{Th}$ in the sediment samples $\left(\mathrm{K}^{\mathrm{s}}\right)$ was significantly higher compared to ${ }^{232} \mathrm{Th}$ in the water samples $\left(\mathrm{K}^{\mathrm{w}}\right)$ (refer to Table 2$)$.

Table 2. Concentration of NORM in water and sediment samples

\begin{tabular}{|c|c|c|c|c|c|}
\hline \multirow{2}{*}{ Type of Sample } & \multirow{2}{*}{ Sample } & \multicolumn{4}{|c|}{ Concentration of Radionuclides $(\mathrm{Bq} / \mathrm{L}) *$ or $(\mathrm{Bq} / \mathrm{kg}) * *$} \\
\hline & & ${ }^{40} \mathbf{K}$ & ${ }^{226} \mathbf{R a}$ & ${ }^{232} \mathrm{Th}$ & ${ }^{238} \mathbf{U}$ \\
\hline \multirow[t]{6}{*}{ Water } & $\mathrm{K}^{\mathrm{w}}$ (KUIS's lake) & $0.62 \pm 0.37$ & $0.19 \pm 0.1$ & $0.04 \pm 0.02$ & $0.44 \pm 0.31$ \\
\hline & $\mathrm{S}^{\mathrm{w}}$ (control) & bdl & bdl & $0.13 \pm 0.01$ & Bdl \\
\hline & Taman Dengkil Jaya Lake [11] & $11.44 \pm 2.04$ & $0.76 \pm 0.07$ & $1.57 \pm 0.33$ & $1.4 \pm 0.15$ \\
\hline & Amang processing plant pool [29] & - & - & $29.59-36.16$ & $28.98-35.42$ \\
\hline & Kapal 7 Lake, Kampung Gajah [1] & $12.8 \pm 2.26$ & $1.66 \pm 0.30$ & - & - \\
\hline & WHO [30] & - & 1 & 1 & 10 \\
\hline \multirow[t]{6}{*}{ Sediment } & $\mathrm{K}^{\mathrm{s}}$ (KUIS lake) & $297.1 \pm 25.7$ & $133.2 \pm 18.8$ & $102.3 \pm 3.3$ & $49.1 \pm 18.8$ \\
\hline & $S^{s}$ (control) & $199.1 \pm 30.5$ & $46.5 \pm 21.6$ & $48.9 \pm 36.9$ & $30.3 \pm 21.6$ \\
\hline & Amang processing plant pool [29] & - & - & 154.4-1966.6 & $262.9-1110.5$ \\
\hline & Chini lake [31] & 618.3 & - & 160.3 & 191 \\
\hline & Kapal 7 Lake, Kampung Gajah [1] & $1782 \pm 201$ & $249.8 \pm 19.5$ & - & - \\
\hline & UNSCEAR [19] & 310 & 67 & 82 & 66 \\
\hline
\end{tabular}

*Unit for water sample, ** Unit for sediment sample, bdl is below detection limit, $\mathrm{K}^{\mathrm{s}}$ is average value for $\mathrm{K} 1$, $\mathrm{K} 2$, $\mathrm{K} 3$, and $\mathrm{K} 4$ in sediment sample

The concentration of NORM $\left({ }^{40} \mathrm{~K},{ }^{226} \mathrm{Ra},{ }^{232} \mathrm{Th}\right.$, and $\left.{ }^{238} \mathrm{U}\right)$ in the water sample $\left(\mathrm{K}^{\mathrm{w}}\right)$ in the current study was lowered compared to the study reported in the ex-mining area at Taman Dengkil Jaya Lake [11]. The higher concentration of NORM in Taman Dengkil Jaya Lake could be contributed from the tailing processing plant, which is located nearby 
studied area. A higher concentration of NORM was also reported from the study by Yasir et al. [29] at the Amang processing plant in Perak with $30-36 \mathrm{~Bq} / \mathrm{L}$ for ${ }^{232} \mathrm{Th}$ and ${ }^{238} \mathrm{U}$, compared to 0.04 and $0.44 \mathrm{~Bq} / \mathrm{L}$ for ${ }^{232} \mathrm{Th}$ and ${ }^{238} \mathrm{U}$ in the current study. A lower concentration of NORM in the current study compared to other studies, including the study reported by Saat et al. [1], indicates that the concentration of NORM at KUIS lake was considered not highly contaminated for the public.

The concentration of NORM obtained from the water sample was also compared with the guidelines for drinking water quality from the World Health Organization. The standard value for the concentration of radionuclides stated by $\mathrm{WHO}$ in ${ }^{238} \mathrm{U},{ }^{232} \mathrm{Th}$, and ${ }^{226} \mathrm{Ra}$ drinking water were $10 \mathrm{~Bq} / \mathrm{L}, 1 \mathrm{~Bq} / \mathrm{L}$, and $1 \mathrm{~Bq} / \mathrm{L}$, respectively [30]. Based on Table 2, the results showed that the concentrations of ${ }^{238} \mathrm{U}(0.44 \pm 0.31 \mathrm{~Bq} / \mathrm{L}),{ }^{232} \mathrm{Th}(0.04 \pm 0.02 \mathrm{~Bq} / \mathrm{L})$, and ${ }^{226} \mathrm{Ra}$ $(0.19 \pm 0.11 \mathrm{~Bq} / \mathrm{L})$ in water samples were below the recommended values by WHO for drinking water sources, which implied the safe consumption of the water. A previous study by Sharip et al. [32] applied the National Quality Water Standard (NQWS) Malaysia to classify water quality at 15 lakes in Malaysia. In the study, the lake $\mathrm{pH}$ was between class II and III and the dissolved oxygen was in class II, according to NQWS [33]. However, based on NQWS, these lakes need to be treated before consumption, as other parameters involved, such as the $\mathrm{pH}$ and dissolved oxygen, must be considered to fulfil the standard requirements [33].

All radionuclides $\left({ }^{40} \mathrm{~K},{ }^{226} \mathrm{Ra},{ }^{232} \mathrm{Th}\right.$, and $\left.{ }^{238} \mathrm{U}\right)$ were detected in the sediment sample in this study $\left(\mathrm{K}^{\mathrm{s}}\right)$ with the highest concentration of ${ }^{40} \mathrm{~K}(199.1 \pm 30.5 \mathrm{~Bq} / \mathrm{kg})$ compared to other radionuclides, which is similar to the trend observed in water samples. In general, all radionuclides $\left({ }^{40} \mathrm{~K},{ }^{226} \mathrm{Ra},{ }^{232} \mathrm{Th}\right.$, and $\left.{ }^{238} \mathrm{U}\right)$ in the sediment of $\mathrm{K}^{\mathrm{s}}$ were significantly higher compared to the control sample $\left(S^{\mathrm{S}}\right)$. The higher concentration of radionuclides obtained in both water and sediment samples compared to the control sample is possibly due to the enhancement of the radionuclide concentration from the former mining activities in that area.

The concentration of ${ }^{232} \mathrm{Th}$ and ${ }^{238} \mathrm{U}$ in the sediment in this study was lowered compared to the Amang processing plant pool [29] in Perak and Chini lake [31]. The higher concentration of ${ }^{232} \mathrm{Th}$ and ${ }^{238} \mathrm{U}$ in Chini lake compared to the current study is possibly due to the development in that area [34], the geological condition, tourism activities, and logging activities, which affect the distribution and enrichment of the natural radionuclides in the sediment. Similar factors might also contribute to the higher concentration of ${ }^{40} \mathrm{~K}$ and ${ }^{226} \mathrm{Ra}$ in Kapal 7 Lake, Kampung Gajah (former mining site). Overall, all radionuclides in sediments were found to be below the safe value reported by UNSCEAR except for ${ }^{226} \mathrm{Ra}$. The higher concentration of ${ }^{226} \mathrm{Ra}$ in this study compared to UNSCEAR might be due to the desorption process occurring on the suspended sediment [34].

\section{Heavy metals}

Based on Table 3, the toxic heavy metal Ba was detected in both water and sediment samples $\left(\mathrm{K}^{\mathrm{w}}\right.$ and $\left.\mathrm{K}^{\mathrm{s}}\right)$; however, the concentration of $\mathrm{Ba}$ was below the standard value for drinking water reported by United States Environmental Protection Agency (US EPA) [35] and WHO [30]. Other heavy metals, such as As, Cu, Sb, and Sn, were detected in the water sample at $\mathrm{K}^{\mathrm{w}}$. These heavy metals were classified as very toxic and relatively accessible. However, these heavy metals were present in very low concentrations $(0.004-0.58 \mu \mathrm{g} / \mathrm{L})$, and most of these heavy metals did not exceed the recommended value by the Ministry of Health (MOH) [36] , US EPA [35] and WHO [30] as shown in Table 3.

The concentration of heavy metals in this study was higher in sediment compared to water samples. In addition, $\mathrm{Zn}$ was found to have the highest concentration compared to other heavy metals in the sediment with an average of $17 \mathrm{mg} / \mathrm{kg}$. According to Moore et al., the concentration of heavy metals that does not show toxicity was in the range of $5-15 \mathrm{mg} / \mathrm{kg}$ [37]. The concentration of heavy metals depends on the types of sediment, and size of the sediment plays an important role to determine the ability of the sediment to absorb metals [38]. This is due to the properties of the sediment, which is composed of fine sand and silt; thus, heavy metals can be easily trapped in sediment due to its stable condition [39]. Singh et al. also showed that the concentration of heavy metals in sediment was higher than in water in their previous research at Gonti river [40]. The higher concentration of heavy metals in sediment compared to water is possibly due to the heavy metals in the water deposited in the sediment. 


\section{Nur Ain et al: DETERMINATION OF NATURAL RADIOACTIVITY AND HEAVY METALS AT THE FORMER MINING SITE OF KOLEJ UNIVERSITI ISLAM ANTARABANGSA SELANGOR (KUIS) LAKE}

The results obtained from this study were also compared to the previous study on Bera Lake [41] and Antartuk Lake [42] in which both lakes reported higher concentrations of heavy metals present compared to the current study, possibly due to the different geological characteristics. Bera Lake is a natural freshwater lake [41], while Antaturk Lake is a dam that is the largest on earth and a rock embankment [42].The concentration of heavy metals in sediment was also compared with the US EPA standard. Referring to the Table 3, all heavy metals were below the standard value for freshwater sediment provided by the US EPA [43].

Table 3. Concentration of heavy metals in water and sediment

\begin{tabular}{|c|c|c|c|c|c|c|c|c|}
\hline \multirow{2}{*}{ Sample } & \multirow{2}{*}{ Location } & \multicolumn{7}{|c|}{ Concentration of Heavy Metal $(\mu \mathrm{g} / \mathrm{L}) *$ or $(\mathrm{mg} / \mathrm{kg}) * *$} \\
\hline & & $\mathbf{B a}$ & As & $\mathrm{Cu}$ & Mn & $\mathrm{Sb}$ & Sn & $\mathbf{Z n}$ \\
\hline \multirow[t]{6}{*}{ Water } & $\mathrm{K}^{\mathrm{w}}$ (lake area) & $0.29 \pm 0.02$ & $0.58 \pm 0.26$ & $0.49 \pm 0.10$ & bdl & 0.01 & 0.004 & bdl \\
\hline & $\mathrm{S}^{\mathrm{w}}$ (control) & $0.62 \pm 0.21$ & bdl & $1.03 \pm 0.32$ & 0.03 & 0.47 & 0.01 & bdl \\
\hline & $\begin{array}{l}\text { Bestari Jaya } \\
\text { Lake [21] }\end{array}$ & - & $79 \pm 9.8$ & $125 \pm 9.94$ & $85 \pm 6.92$ & - & $404 \pm 53.46$ & $115 \pm 10.24$ \\
\hline & MOH [36] & - & 10 & 1000 & 200 & - & - & 300 \\
\hline & US EPA [35] & 200 & 10 & - & - & 6 & - & - \\
\hline & WHO [30] & 700 & 10 & 2000 & - & 20 & - & - \\
\hline \multirow[t]{7}{*}{ Sediment } & $\mathrm{K}^{\mathrm{s}}$ (lake area) & $1.30 \pm 0.37$ & $2.06 \pm 1.03$ & 0.99 & $9.74 \pm 1.90$ & $0.04 \pm 0.02$ & $0.41 \pm 0.14$ & $17.34 \pm 15.79$ \\
\hline & $\mathrm{S}^{\mathrm{s}}$ (control) & $0.73 \pm 0.66$ & $4.37 \pm 0.57$ & 2.54 & 30.37 & 0.03 & $0.41 \pm 0.58$ & $12.83 \pm 5.5$ \\
\hline & $\begin{array}{l}\text { Peninsular } \\
\text { Malaysia } \\
\text { (ex-tin mining } \\
\text { lake) [44] }\end{array}$ & - & $48.9 \pm 9.6$ & $19.24 \pm 0.89$ & $407.9 \pm 68.3$ & - & - & $199.1 \pm 17.6$ \\
\hline & Bera Lake [41] & - & 139.0 & 2312 & 449 & - & - & 94 \\
\hline & $\begin{array}{l}\text { Gonti River } \\
\text { [40] }\end{array}$ & - & - & 5.0 & 148.13 & - & - & 41.67 \\
\hline & $\begin{array}{l}\text { Ataturk Lake } \\
\text { [42] }\end{array}$ & - & - & 14.57 & 514.07 & - & - & 59.24 \\
\hline & US EPA [43] & - & 9.8 & 31.6 & 460 & 2 & - & 121 \\
\hline
\end{tabular}

* Unit for water sample, ** Unit for sediment sample, bdl is below detection limit

\section{Radiological hazards}

The radiological hazards, which include a Radium-equivalent Activity Index $\left(R a_{e q}\right)$, Gamma Index $\left(I_{\gamma}\right)$, External Hazard Index $\left(H_{e x}\right)$, Internal Hazard Index $\left(H_{i n}\right)$, absorbed dose $(D)$, and effective dose $\left(D_{e f f}\right)$ in this study were presented in Table 4 . The $R a_{e q}$ in $\mathrm{K}^{\mathrm{s}}$ was $225.5 \mathrm{~Bq} / \mathrm{kg}$, less than the recommended maximum levels by NEA-OECD (370 Bq/kg) [16]. Similar trends were recorded for the $H_{e x}$ and $H_{i n}$ with the values of (0.6) and (0.9), less than the unity value of 1 [17]. In addition, the $D_{\text {eff }}(0.10 \mathrm{mSv} / \mathrm{y})$ was lowered compared to the range proposed by UNSCEAR $2000(1-10 \mathrm{mSv} / \mathrm{y})$ [19], whereas $I_{\gamma}$ was measured at $\geq 1$. In general, the values for $R a_{e q}, H_{e x}, H_{i n}, D$, and $D_{e f f}$ in both the control and KUIS lake $\left(\mathrm{S}^{\mathrm{S}}\right.$ and $\mathrm{K}^{\mathrm{S}}$ ) were below the recommended value, thus indicating a safe environment around KUIS lake for any recreational activities.

Table 4 also summarized the radiation hazard in sediment obtained in some of the regions around Malaysia. For example, $R a_{e q}, I_{\gamma}, H_{e x}, H_{i n}, D$, and $D_{\text {eff }}$ that were measured in this study were approximately similar to the results 
obtained in the northern peninsular area [10] but were slightly higher than the value reported in Jengka 15 [5], Pahang and in the east coast peninsular area [45].

Table 4. Comparison radiation hazard indices in this study and other studies in some regions in Malaysia

\begin{tabular}{lcccccc}
\hline Location & $\begin{array}{c}\mathbf{R a}_{\text {eq }} \\
(\mathbf{B q} / \mathbf{k g})\end{array}$ & $\begin{array}{c}\mathbf{I}_{\gamma} \\
(\mathbf{B q} / \mathbf{k g})\end{array}$ & $\mathbf{H}_{\text {ex }}$ & $\mathbf{H}_{\text {in }}$ & $\begin{array}{c}\mathbf{D} \\
(\mathbf{n G y / h})\end{array}$ & $\begin{array}{c}\mathbf{D}_{\text {eff }} \\
(\mathbf{m S v} / \mathbf{y})\end{array}$ \\
\hline $\mathrm{K}^{\mathrm{s}}$ (lake area) & 225.5 & 1.6 & 0.6 & 0.9 & 104.1 & 0.1 \\
$\mathrm{~S}^{\mathrm{s}}$ (control) & 90.9 & 0.7 & 0.2 & 0.4 & 42.4 & 0.1 \\
Jengka 15, Pahang [5] & - & - & $0.08-0.31$ & - & $13-50$ & - \\
Northern Peninsular [10] & $63-414$ & - & $0.17-1.1$ & $0.21-1.61$ & $29-188$ & $0.036-0.231$ \\
East Coast Peninsular [45] & 143.1 & - & 0.4 & - & - & - \\
\hline
\end{tabular}

\section{Conclusion}

This study represents the comprehensive investigation on the determination of the concentrations of natural radionuclides, heavy metals, and radiological hazards at the former mining area of KUIS lake. Results showed that the concentration of ${ }^{40} \mathrm{~K}$ was the highest, followed by ${ }^{238} \mathrm{U},{ }^{226} \mathrm{Ra}$, and ${ }^{232} \mathrm{Th}$ in the water samples. Similarly, the concentration of ${ }^{40} \mathrm{~K}$ was found to be the highest in the sediment sample, followed by ${ }^{226} \mathrm{Ra},{ }^{238} \mathrm{U}$, and ${ }^{232} \mathrm{Th}$. The radionuclides concentration in water obtained in this study was still in the safe limit to become a source of drinking water. In the sediment matrix, the highest heavy metal reading was $\mathrm{Zn}$ whereas the highest heavy metal reading was As in the water sample. Based on the radiation hazard index level in the current study, KUIS Lake was found to be safe for the public to perform any activities; however, occasional monitoring still needs to be considered in the future. For future prospects, the study of concentrations of natural radionuclides and heavy metals in biotic samples, such as fish and plants surrounding the lake area can provide a very good indicator of the complete transfer factor of the lake ecosystem.

\section{Acknowledgements}

The authors wish to thank the School of Applied Physics, UKM, especially the Nuclear Science Programme, GGPM-2015-038, and GUP-2017-085 for the funds. The authors acknowledge Mr Azman, Senior Assistant Architect Landscape of Kolej University Islam Antarabangsa Selangor (KUIS) for his cooperation throughout the research. The authors also acknowledge the facilities of the School of Environmental Science, UKM for assistance with the ICP-MS analysis.

\section{References}

1. Saat, A., Isak, N. M., Hamzah, Z. and Wood, A. K. (2014). Study of radionuclides linkage between fish, water and sediment in former tin mining lake in Kampung Gajah, Perak. Malaysian Journal of Analytical Sciences, 18(1): 170-177.

2. Irvin, T. R. and Cruz-Batres, C. (1996). Naturally occurring radioactive material:Principles and practices. St. Lucoe Press, Delray Beach, Florida: pp. 2-3.

3. Avwiri, G. O., Ononugbo, C. P. and Nwokeoji, I. E. (2014). Radiation hazard indices and excess lifetime cancer risk in soil, sediment and water around Mini-Okoro/Oginigba Creek, Port Harcourt, River State, Nigeria. Journal of Environment and Earth Sciences, 3(1): 38-50

4. Al-Hamarneh, I. F. and Awadallah, M. I. (2009). Soil radioactivity levels and radiation hazard assessment in the highlands of northern Jordan. Radiation Measurements, 44(1): 102-110.

5. Alias, M., Hamzah, Z., Saat, A., Omar, M. and Wood, A.K. (2008). An assessment of absorbed dose and radiation hazard index from natural radioactivity. Malaysian Journal of Analytical Sciences, 12(1): 195-204.

6. Taskin, H., Karavus, M., Ay, P., Topuzoglu, A., Hidiroglu, S. and Karahan, G. (2009). Radionuclide concentrations in soil and lifetime cancer risk due to gamma radioactivity in Kirklareli, Turkey. Journal of Environmental Radioactivity, 100(1): 49-53. 
Nur Ain et al: DETERMINATION OF NATURAL RADIOACTIVITY AND HEAVY METALS AT THE FORMER MINING SITE OF KOLEJ UNIVERSITI ISLAM ANTARABANGSA SELANGOR (KUIS) LAKE

7. Erickson, A. J., Weiss, P. T. and Gulliver, J. S. (2013). Water sampling methods: pp. 163-192.

8. Yasir, M. S., Kabir, N. A., Yahaya, R. and Majid, A. A. (2008). Kandungan logam berat dan radionuklid tabii dalam ikan, air, tumbuhan dan sedimen.Malaysian Journal of Analytical Sciences, 12 (1): 172-178.

9. Nasirian, M., Bahari, I. and Abdullah, P. (2008). Assessment of natural radioactivity in water and sediment from amang (tin tailing) processing ponds. Malaysia Journal of Analytical Sciences, 12(1): 150-159.

10. Almayahi, B. A., Tajuddin, A. A. and Jaafar, M. S. (2012). Radiation hazard indices of soil and water samples in Northern Malaysian Peninsula. Applied Radiation and Isotopes, 70(11): 2652-2660.

11. Yasir, M. S., Ab. Majid, A., Ibrahim, F., Tap, S. Q. M. and Abidin, M. R. Z. (2006). Analisis ${ }^{238}$ U, ${ }^{232}$ Th dan ${ }^{40} \mathrm{~K}$ dalam sampel amang, tanah dan air di Dengkil, Selangor menggunakan spektrometri gama. Malaysian Journal of Analytical Sciences, 10(1): 35-40.

12. United States Environmental Protection Agency (2014). Method 6020B: Inductively coupled plasma - mass spectrometry, part of test methods for evaluating solid waste, physical/chemical methods. Washington DC: pp. $1-33$.

13. Talib, O. (2015). SPSS: Analissis data kuantitatif untuk penyelidik muda. MPWS Rich Publication Sdn Bhd, Bangi, Selangor: pp. 4-215.

14. Harb, S., El-Kamel, A.H., El-Mageed, A.I.A., Abbady, A. and Rashed, W. (2008). Concentration of U-238, Ra226 Th-232 and K-40 for some granite samples in Eastern Desert of Egypt. Proceedings of the 3rd Environmental Physics Conference, Aswan, Egypt: 109-117.

15. Organisation for Economic Cooperation and Development. (1979). Exposure to radiation from natural radioactivity in building materials. France: pp. 1-40.

16. Guptaa, M., Chauhana, R. P., Gargb, A., Kumarc, S. and Sonkawaded, R. G. (2010). Estimation of radioactivity in some sand and soil samples. Indian Journal of Pure \& Applied Physics, 48: 482-485.

17. Diab, H. M., Nouh, S. A., Hamdy, A. and El-Fiki, S. A. (2008). Evaluation of natural radioactivity in a cultivated area around a fertiliser factory. Journal of Nuclear and Radiation Physics, 3(1): 53-62.

18. United Nations Scientific Committee on the Effects of Atomic Radiation (1977). Sources and effects of ionizing radiation. Annex A:Concepts and quantities in the assessment of human exposures. New York.

19. United Nations Scientific Committee on the Effects of Atomic Radiation (2000). Annex B-exposures from natural radiation sources. New York.

20. Hirner, A.V. (2016). Environmental impacts of metallic elements: Speciation, bioavailability and remediation, in Environmental Earth Sciences, Sarfraz M. Ashraf M. A., Naureen R., Gharibreza M, Editor. Springer, Berlin: pp. 1183.

21. Ashraf, M. A., Maah, M. J. and Yusoff, I. B. (2010). Study of water quality and heavy metals in soil \& water of ex-mining area Bestari Jaya, Peninsular Malaysia. International Journal of Basic \& Applied Sciences, 10(03): 7-23.

22. Al-Badaii, F., Shuhaimi-Othman, M. and Gasim, M. B. (2013). Water quality assessment of the Semenyih River, Selangor, Malaysia. Journal of Chemistry, 2013: 1-10.

23. National Hydraulic Research Institute of Malaysia and Ministry of Natural Resources and Environment. (2015). National Lake Water Quality Criteria and Standards. Malaysia. Access from http://www.nahrim.gov.my/en/publications/listofpublications/1195-national-lake-water-quality-criteria-andstandards.html.

24. Wetzel, R. G. (2001). Limnology, lake and river ecosystem. Elsvier, United States.

25. Chapman D. (1996). Water quality assessments - A guide to use of biota, sediments and water in environmental monitoring. University Press, Cambridge. Great Britain: pp. 1-609.

26. Schmus, W. R. V. (1995). Global earth geophysics: A handbook of physical constants. American Geophysical Union, USA: pp. 1-376.

27. Kathren, R. L. (1998). NORM sources and their origins. Applied Radiation and Isotopes, 49(3): 149-168.

28. Boyle, R.W. (1982). Geochemical prospecting for thorium and uranium - Hydrochemical Surveys. Elsevier: pp. 277-315.

29. Yasir, M. S., Majid, A. A., Yahaya, R., Bahari, I. and Kim, W. S. (2007). Impak aktiviti pemprosesan amang sistem tertutup ke atas kualiti air dan sedimen setempat. Malaysian Journal of Analytical Sciences, 11(2): 370 378.

30. World Health Organisation (2011). Guidelines for drinking-water quality. $\left(4^{\text {th }}\right)$ WHO Press. Switzerland: pp. 1-564. 
31. Majid, A., Umar, S. R., Yahaya, R., Yasir, M. S. and Othman, M. S. (2008). Analisis unsur dan keradioaktifan dalam sampel sedimen Tasik Chini, Pahang Darul Makmur. Malaysian Journal of Analytical Sciences, 12(1): 167-171.

32. Sharip, Z., Zaki, A. T. A., Shapai, M. A. H. M., Suratman, S. and Shaaban, A. J. (2014). Lakes of Malaysia: Water quality, eutrophication and management. Lakes and Reservoirs: Research and Management, 19(2): 130141.

33. Water Environment Partnership in Asia. (2008). National water quality standards for Malaysia. Access from http://wepa-db.net/3rd/jp/topic/waterstandard/Malaysia_1_surface.pdf.

34. Mohamed, C. A. R., Ahmad, Z. and Mon, G. C. (2006). Aktiviti Ra ${ }^{226}$ dalam sistem aliran sungai lembangan Langat, Selangor. Malaysian Journal of Analytical Sciences, 10(2): 295-302.

35. United States Environmental Protection Agency (2009). National Primary Drinking Water Regulations. Access from https://www.epa.gov/ground-water-and-drinking-water/national-primary-drinking-water-regulations.

36. Ministry of Health Malaysia (2000). National water quality standards for Malaysia.Access from https://environment.com.my/wp-content/uploads/2016/05/Drinking-Water-MOH.pdf.

37. Moore, J.W. and Ramamoorthy, S. (1984). Heavy Metals in Natural Waters: Applied Monitoring and Impact Assessment. Springer-Verlag New York Inc: 1-269.

38. Greaney, K. M. (2005). An assessment of heavy metal contamination in the marine sediments of Las Perlas Archipelago, Gulf of Panama. Thesis of Master Degree. Heriot-Watt University, Edinburgh, UK.

39. Hamzah, Z., Saat, A., Bakar, Z. A. and Wood, A. K. (2011). Anthropogenic heavy metals, U-238 and Th-232 profiles in sediments from an abandoned tin mining lake in Malaysia. $3^{\text {rd }}$ International Conference on Chemical, Biological and Environmental Engineering, 2011:75-79.

40. Singh, K. P., Mohan, D., Singh, V. K. and Malik, A. (2005). Studies on distribution and fractionation of heavy metals in Gomti river sediments - a tributary of the Ganges, India. Journal of Hydrology, 312 (1-4): 14-27.

41. Gharibreza, M., Ashraf, M. A., Yusoff, I. and Raj, J. K. (2013). An evaluation of Bera Lake (Malaysia) sediment contamination using sediment quality guidelines. Journal of Chemistry, 2013: 1-13.

42. Karadede, H. and Unlu, E. (2000). Concentrations of some heavy metals in water, sediment and fish species from the Atatürk Dam Lake (Euphrates). Chemosphere, 41: 1371-1376.

43. United States Environmental Protection Agency (2006). Freshwater Sediment Screening Benchmarks. Access from https://www.epa.gov/sites/production/files/2015-09/documents/r3_btag_fw_sediment_ benchmarks_806.pdf

44. Hamzah, Z., Saat, A., Wood, A. K. and Bakar, Z. A. (2011). Sedimentation, heavy metals profiles and cluster analysis of a former tin mining lake. International Journal of Environmental Science and Development, 2(6): 448-453.

45. Mei-Wo, Y., Jaffary, N. A. M. and Ahmad, Z. (2011). Radiation hazard from natural radioactivity in the sediment of the East Coast Peninsular Malaysia Exclusive Economic Zone (EEZ). Malaysian Journal of Analytical Sciences, 15(2): 202-121. 